\title{
A Tale of Two Basins: The Role of Peptide Deamination in the Accumulation of Pore Water Dissolved Organic Matter in Marine Sediments.
}

H. A. ABDUlLA ${ }^{1 *}$, T. KOMADA ${ }^{2}$ AND D .J. BURDIGE ${ }^{3}$

${ }^{1}$ Department of Physical and Environmental Sciences, Texas A\&M University - Corpus Christi, Corpus Christi TX 78412, USA (*correspondence: hussain.abdulla@tamucc.edu)

${ }^{2}$ Estuary \& Ocean Science Center, San Francisco State University, Tiburon CA, 94920, USA (tkomada@sfsu.edu)

${ }^{3}$ Department of Ocean, Earth and Atmospheric Sciences, Old Dominion University, Norfolk, VA 23529, USA

(dburdige@odu.edu)

In general, marine sediment pore water has higher concentrations of dissolved organic matter (DOM) relative to the overlying water column. This makes marine sediments a significant source of DOM to the water column. The mechanisms of pore water DOM production and the reasons why it may be difficult for microbes to degrade this material remain unclear, because we lack molecular level understanding of pore water DOM. Proteins account for the majority of biomolecules produced in the marine environment and constitute an important component of the organic matter supplied to the seafloor. Degradation of proteins within the sediment column should therefore be an integral part of porewater DOM production and transformation. Here we present how incomplete hydrolysis of proteins and peptides to free amino acids leads to catabolic deamination of non-hydrolyzed peptides. Using state-of-the-art analytical techniques, we have indentified and quantified peptides and deaminated peptides accumulating in the sediment pore waters of Santa Barbara and Santa Catalina Basins in the California Borderlands. These two sites are fine-grained and relatively organic-rich, yet vary in degrees of oxygenation, bioturbation and bioirrigation, and sedimentation rate. This work contributes to a foundational understanding of the relationship between protein and peptide dynamics, sediment DOM cycling, and the role of sediments as a source of refractory DOM to the water column. 